\title{
DINAMIKA PENGGUNAAN RAGAM BAHASA DIALEK JAWA BARAT: ANTARA POLITIK DAN DEMOKRASI
}

\author{
Juanda \\ Fakultas Sastra Unikom \\ E-mail:djuanda1969@yahoo.com
}

\begin{abstract}
Abstrak
Bahasa Sunda merupakan bahasa dialek yang ada di Jawa Barat. Bahasa Sunda saat ini masih digunakan oleh para penuturnya untuk komunikasi sehari-hari, Namun, dalam penggunaannya, bahasa Sunda di perkotaan sudah mulai tergeser oleh bahasa asing atau bahasa Indonesia walaupun sebenarnya pemerintah sudah ada upaya memasukkan mata pelajaran bahasa Sunda pada pendidikan formal mulai dari pendidikan dasar sampai tingkat menengah. Program pemerintah ini nampaknya belum begitu memberikan hasil yang menggembirakan dalam peningkatan kompetensi berkomunikasi dalam bahasa Sunda. Salah satu hal yang menjadi fenomena dalam penggunaan bahasa Sunda adalah penerapan "undak usuk basa". Faktor penyebab semakin menurunnya kemampuan penggunaan ragam bahasa ini adalah tidak pernah dibiasakannya penggunaan ragam bahasa tersebut baik di lingkungan formal maupun di lingkungan nonformal seperti lingkungan keluarga atau masyarakat Beberapa kosakata yang mulai tidak dikenali masyarakat terutama kalangan pelajar atau mahasiswa seperti penggunaan kata astana, pasarean, pajaratan. Kata ini memiliki arti yang sama artinya makam. Namun, Kata ini sering diganti dengan kata makam atau kuburan dalam komunikasi sehari-hari, seharusnya kata tersebut digunakan sesuai dengan ragamnya. Astana untuk loma, pasarean untuk bahasa halus buat diri sendiri, sedangkan pajaratan bahasa halus untuk orang lain. Contoh :"Luhureun pasir eta teh aya astana", "Pasarean pun adi teh tacan ditembok da taneuhna tacan padet", "pajaratan pun aki mah dicirian ku hanjuang beureum". Tulisan ini mencoba mengangkat beberapa kosakata bahasa Sunda yang masih dirasakan asing oleh penutur aslinya dan belum diterapkan dalam kehidupan seharihari, Tujuannya untuk lebih memperkenalkan lagi atau mengingatkan lagi bentuk-bentuk kosakata yang seharusnya dipilih. Dari sudut pandang politik berbahasa bahwa penerapan ragam bahasa atau undak-usuk bahasa ini merupakan bagian berbudaya bahasa lokal yang harus dilestarikan sementara sisi demokrasi bahwa setiap penutur memiliki kebabasan untuk menggunakan ataupun tidak.
\end{abstract}

Kata kunci: dialek, ragam bahasa, bahasa halus, bahasa loma

\section{PENDAHULUAN}

Ragam bahasa atau dikenal dengan undakusuk basa dalam bahasa Sunda merupakan sebuah penerapan penggunaan bahasa atau pragmatik yang di dalamnya terdapat tatakrama berbahasa. Tatakrama bahasa merupakan sebuah cara berkomunikasi untuk menghargai orang lain oleh perbedaan struktur sosial, yang hakikatnya merupakan sebuah bentuk penghargaan pada diri sendiri. Munculnya ragam hormat dan loma salah satunya disebabkan adanya struktur sosial (Yudibrata, 1990: 43). Tujuan diterapkannya undak usuk basa bukan untuk membeda-bedakan strata sosial tertentu melainkan untuk saling menghargai di antara penutur. Seperti halnya 
seorang mahasiswa ketika berkomunikasi dengan dosen akan berbeda undak usuknya ketika berkomunikasi dengan teman sekelasnya.

Kalau kita melihat sejarah munculnya undak usuk basa sebetulnya sudah ada sejak Zaman Kerajaan Mataram (Faturohman, 1982: 49). Ketika masyarakat tatar Sunda datang ke Mataram untuk membayar upeti, mereka mempelajari budaya salah satunya bahasa yang ada tingkatan berbahasanya, Saat kembali ke tatar Sunda penggunaaan undakusuk berbahasa tersebut diterapkan dalam bahasa Sunda. Oleh karena itu muncullah yang disebut dengan undak-usuk basa tersebut yang sekarang dikenal dengan ragam bahasa yakni ragam hormat dan ragam loma. Ragam hormat dibagi dua yakni, ragam hormat untuk diri sendiri dan orang lain (Hadi, 1991:12). Sementara masyarakat

Filosofi ragam bahasa sebenarnya berbeda saat dulu dan sekarang. Zaman dulu lebih cenderung untuk membedakan strata sosial, tetapi saat ini paradigmanya sudah ke arah bentuk sebuah penghormatan kepada diri sendiri dengan cara menghormati orang lain. Kita bisa membandingkan kalimat-kalimat berikut:

Bapak sasuran palay dipanggaleuhkeub raksukan.

Abdi nyarios hoyong dipangmeserkeun anggoan.

Kuring nyarita hayang dipangmeserkeun pakean. (Yudibrata, 1990: 42)

Kalimat-kalimat di atas menunjukkan sebuah penerapan ragam bahasa hormat baik untuk diri sendiri maupun untuk orang lain. Bentuk yang satunya lagi merupakan bahasa loma.

Masyarakat di perkotaan Jawa Barat saaat ini sterutama kalangan remaja atau usia sekolah sudah mulai kurang memahami penerapan ragam bahasa hal ini terlihat dalam obrolan sehari-hari ketika mereka berada di rumah makan, di terminal, atau di tempat-tempat umum. Bahasa Sunda yang mereka gunakan cenderung bahasa Sunda kasar. Terkait dengan fenomena ini pemerintah pun melakukan upaya salah satunya memasukkan mata pelajaran bahasa Sunda bagi siswa tingkat pendidikan dasar dan selanjutnya pada tingkat menengah. Hal ini merupakan sebuah alternatif untuk mempertahankan bahasa daerah yang merupakan sebagai pemerkaya bahasa nasional.

\section{METODOLOGI}

\section{a. Subjek dan Objek Penelitian}

Subjek penelitian adalah mahasiswa Sastra Inggris Unikom semester I tahun akademik 2017/2018 sejumlah 25 mahasiswa dan beberapa masyarakat Kota Bandung secara random sedangkan objek peneliian adalah penggunaan ragam bahasa Sunda.

\section{b. Metode Pengumpulan Data}

Metode yang digunakan dalam penelitian ini merupakan metode deskriptif melalui survei lapangan dan kuesioner. Survei dengan cara dengar dan catat yang dilakukan di lokasi-lokasi perbelanjaan, tempat-tempat mangkal seperti cafe/rumah makan, dan beberapa kuesionar yang berkaitan dengan ragam bahasa Sunda.

\section{c. Instrumen Penelitian}

Pendokumentasian data-data yang diperoleh disimpan dalam bank data ragam bahasa.

\section{e. Metode Analisis Data}

Metode analisis data menggunakan analisis deskriptif kualitatif dengan cara menggambarkan dan mendeskripsikan data temuan ragam bahasa Sunda dengan cara mengaitkan teori dan hasil temuan.

\section{PEMBAHASAN}

Penggunaan ragam bahasa masyarakat Kota Bandung baik di kalangan mahasiswa maupun di kalangan masyarakat umum pada umumnya belum sepenuhnya digunakan secara menyeluruh. Banyak sekali pilihan kata yang tidak sesuai dengan ragam bahasa. Hasil temuan di antaranya penggunaan: 


\begin{tabular}{|c|c|c|c|}
\hline No. & Loma & $\begin{array}{c}\text { Lemes Buat } \\
\text { Sendiri }\end{array}$ & $\begin{array}{c}\text { Lemes Buat } \\
\text { Orang Lain }\end{array}$ \\
\hline 1 & asup & lebet & lebet \\
\hline 2 & keur & kangge & haturan \\
\hline 3 & alus & sae & sae \\
\hline 4 & pamit & permios & permios \\
\hline 5 & anggeus & rengse & parantos \\
\hline 6 & arang & Awis-awis & Awis-awis \\
\hline 7 & arek & bade & bade \\
\hline 8 & asal & kawit & kawit \\
\hline 9 & ngaso & ngaso & leleson \\
\hline 10 & maca & maca & maos \\
\hline 11 & bangga & sesah & sesah \\
\hline 12 & bawa & bantun & candak \\
\hline 13 & kuru & begang & langsip \\
\hline 14 & mere & masihan & ngahaturkeun \\
\hline 15 & meuli & meser & ngagaleuh \\
\hline
\end{tabular}

Berdasarkan hasil kuesionar terhadap mahasiswa ditemukan $85 \%$ mahasiswa menggunakan kosakata yang penerapannya masih belum tepat. Hampir 90\% mahasiswa kesulitan menggunakan bahasa halus untuk orang lain. Mayoritas mahasiswa hampir tidak mengenal kosakata leleson dan langsip. Kata-kata tersebut seolah-olah merupakan kosakata terbaru bagi mereka yang belum sama sekali mereka kenal.

Permasalahan yang muncul bagaimana sebuah politik bahasa dapat menyokong kelestarian bahasa. Politik bahasa (language politics) merupakan sebuah keadaan baik persamaan maupun perbedaan bahasa dituangkan dalam ungkapan kebahasaan, sedangkan bahasa politik merupakan kecenderungan bahasa partisipan politik yang menentukan orientasi dan kecenderungan politik masyarakat. Pada saat Ridwan Kamil menjadi Walikota Bandung banyak istilah-istilah Sunda dipajankan seperti di taman-taman atau trotoar-totoar. Ini berarti keberadaan bahasa Sunda diperpolitikkan oleh warga dalam bentuk ungkapan atau idiom. Ketika kehadiran bahasa Sunda sebagai objek maka bahasa sunda termasuk pada politik kehadiran berbahasa yang akan mendukung politik bahasa nasional. Politik bahasa cenderung berurusan dan penanganan persoalan kehadiran bahasa dan ranah penggunaan bahasa. Dengan munculnya politik bahasa bisa terkait dengan perencanaan, pembakuan dan pembinaan.
Sisi positif peran sebuah politik bahasa untuk menentukan sebuah kebijakan perencanaan, pembakuan, maupun pembinaan dirasakan perlu kehadirannya, tetapi sisi lain sebuah demokrasi kebebasan berbahasa merupakan sebuah tatatanan yang tidak bersifat baku dan kaku yang jadi tolok ukur pegangan masyarakat.

\section{SIMPULAN}

Politik bahasa dan demokrasi berbahasa merupakan dua sudut pandang yang masingmasing memiliki proyeksi tersendiri. Keduanya bisa berjalan berdampingan, bisa juga masing-masing memiliki alur tersendiri. Setiap negara memiliki politik berbahasa untuk mempertahankan bahasa tersebut dari kepunahan dan politik bahasa itu bisa dijadikan sebuah alat untuk mempertahankan eksistensi bahasa tersebut. Namun demikian, sisi lain dalam demokrasi berbahasa kita tidak bisa menghakimi bahwa seseorang itu salah dalam berbahasa apalagi dalam bahasa nonformal. Demokrasi berbahasa dapat terjadi karena alasan latar belakang pendidikan, latar belakang sosial, atau latar belakang yang lainnya.

Dalam demokrasi berbahasa tentu saja akan tercermin sebuah keragaman sebuah tingkat atau tataran kemampuan penerapan sebuah bahasa. Setiap kelompok masyarakat akan terlihat bagaimana mereka mengekplorasi sebuah bahasa tanpa adanya norma-norma yang terlalu mengikat penggunaan bahasa masyarakat bahasa tersebut.

\section{DAFTAR PUSTAKA}

Faturohman, Taufik. 1992. Tatabasa Sunda. Bandung: Djatnika.

Hadi, Ahmad. 1991. Peperenian. Bandung: Geger Sunten.

Rusyana, Yus. 1984. Bahasa dan Sastra dalam Gamitan.Bandung: Diponegoro.

Sumarsono, Tatang. 1984. Pedaran Sastra Sunda. Bandung: Medal Agung.

Yudibrata, Karna, Agus Suriamihara, Iskandarwassid. 1990. Bagbagan Makena Basa Sunda. Bandung: Rahmat Cijulang. 